\title{
Self-Reliant Learning Strategy in Vocational and Technical Education: Insights from Group Collaboration
}

\author{
Muhammad Abdul Hanif Yussop ${ }^{1}$, Masitah Shahrill ${ }^{2 *}$, and Siti Norhedayah Abdul Latif ${ }^{3}$ \\ ${ }^{1}$ Politeknik Brunei, Brunei Darussalam; ${ }^{2,3}$ Sultan Hassanal Bolkiah Institute of Education, Universiti Brunei \\ Darussalam, Brunei Darussalam \\ *e-mail: masitah.shahrill@ubd.edu.bn
}

\begin{abstract}
In this study, a self-reliant learning strategy was used in the teaching and learning of a Mathematics module at a local technical institution to investigate its effectiveness in improving the students' performance in descriptive statistics. This study also examined how group work activity, when integrated with the self-reliant strategy, can contribute to students development in directing their learning. Forty-two students were observed on how a self-reliant learning strategy affects their performance. It is found that the self-reliant learning strategy had a positive impact on the students' performance in their learning of descriptive statistics and that group work activity improved students' learning skills, especially on planning, monitoring, and evaluating their course of learning on their own. The findings of this study hoped to provide pedagogical alternatives and persuade teachers to consider the self-reliant learning strategy that promotes flexibility in the course of the students' learning.
\end{abstract}

Keywords:

Self-Reliant Learning; Self-Regulation; Independence; Group Work

\begin{abstract}
ABSTRAK
Dalam penelitian ini strategi pembelajaran mandiri digunakan dalam proses pembelajaran dan pengajaran modul Matematika di lembaga teknis setempat untuk mengetahui keefektifannya dalam meningkatkan kinerja siswa dalam topik statistik deskriptif. Penelitian ini juga mengkaji bagaimana aktivitas kerja kelompok ketika diintegrasikan dengan strategi kemandirian dapat berkontribusi pada perkembangan siswa dalam mengarahkan pembelajaran mereka sendiri. Ada 42 siswa yang diamati tentang bagaimana strategi pembelajaran mandiri mempengaruhi kinerja mereka. Diketahui bahwa strategi pembelajaran mandiri berdampak positif
\end{abstract}


terhadap kinerja siswa dalam pembelajaran statistik deskriptif, dan kegiatan kerja kelompok meningkatkan keterampilan belajar siswa terutama dalam perencanaan, pemantauan dan evaluasi jalannya pembelajaran mereka sendiri. Temuan penelitian ini diharapkan dapat memberikan alternatif pedagogis dan meyakinkan guru untuk mempertimbangkan strategi pembelajaran mandiri yang mendorong fleksibilitas dalam proses belajar siswa.

Kata kunci:

Pembelajaran Mandiri; Regulasi Diri; Kebebasan; Kerja Kelompok

\section{Introduction}

According to Hoepfner and Koch (2015), a learning strategy that fosters students to be more independent in their learning has more potential to develop the students' academic skills and worklife skills that can be used in the future. Hence, teachers play an essential role in promoting a suitable environment in training students towards becoming self-reliant learners. Studies by Dignath and Büttner (2018) and Müller and Seufert (2018) support the self-regulated learning associated with learning success. While regulation of own learning is essential, collaborative group work is necessary for vocational and technical education because of its application to real work situations (Hoepfner \& Koch, 2015). Peer collaboration has continued to support the students' learning (Perry et al., 2002). However, there was little attention given to how group work is regulated within a learning group.

To be self-reliant is a highly desirable trait of personality. In this $21^{\text {st }}$ century, the demand to encourage students to learn constantly increases exponentially as such in this industrial era where work situations are dynamically complex and more unpredictable (Hoepfner \& Koch, 2015). In order to create such a learning environment in the school, the proportion of responsibilities between teachers and its students in doing actions in class has shifted a lot more to the students. No longer are the teachers seen as the sole transmitters of knowledge and skills but rather as facilitators who are responsible for creating a suitable learning environment for the students towards becoming selfreliant individuals.

Hoepfner and Koch (2015) have provided an instructional learning manual in technical education and vocational training by utilizing the self-reliant learning strategy. They characterized autonomous learning as a "natural way of learning" (Hoepfner \& Koch, 2015, p. 11) where students are learning by doing. Hoepfner and Koch also suggested autonomous learning demands lifelong learning or continuing professional development and the need to be self-devising, self-monitoring, self-evaluating, and teamwork within the learning procedure. They further stated that this circumstance, combined with the tremendous growth of their self-consciousness, resulted in much more independent action. While the self-reliant learning strategy by Hoepfner and Koch outlined the effectiveness in improving Mathematics performance, this has yet to be tested. We know that a 
self-reliant individual with a good confidence level has a more positive outlook and can lead a group towards a successful outcome.

In defining autonomous learning, we shall separate the terms 'self-reliant' and 'learning' to determine their literal definition. The online dictionaries define 'self-reliant' as "not needing help or support from other people" (Cambridge University Press, n.d.) and 'learning' as "the process of gaining knowledge through studying" (Collins, n.d.). Merging the literal meaning implies that autonomous learning is an act of gaining knowledge without the need for external support and guidance. In the educational system, this is not an appropriate definition, to begin with, where guidance and support from the teacher are essential. Hence the literal definition is then limited to certain aspects of acquiring knowledge that will be justified in the following paragraphs.

Looking at epistemologies that support the self-reliant learning theory, in general, the term autonomous learning has not been used extensively to describe learning theory that integrates students' autonomy in the learning process. The synonymous term used that matched with Hoepfner and Koch's (2015) self-reliant learning theory is the self-regulated learning theory described by Loyens et al. (2008). In self-regulated learning, the process involves devising goals, plans, tactics, and strategies based on the task given, concurrently assessing their progress, and improving plans accordingly. Loyens and colleagues reviewed few empirical studies that relate self-regulated learning with problem-centered learning and concluded that the ability of students to self-monitor increases the tendency for the students to improve academic performance. Besides, self-regulated learning is a developmental process that is possible for the students to learn, and it fosters students' independence in controlling their learning (Loyens et al., 2008). Hence, in the pursuit of students' independence in their learning, there are vital elements that should be developed in autonomous learning, and these included: students' active engagement (Loyens et al., 2008, Marshall, 2008); autonomy (Lee \& Hannafin, 2016); and suitable learning environment (Marshall, 2008).

When students recognize the presence of a knowledge gap, they will seek ways to fill the space, demonstrating their in-depth and constructive understanding of the context (Hoepfner \& Koch, 2015). A student is said to be in a state of autonomy when his act naturally satisfies him. It is when the learner has the right to decide the most comfortable way to learn. Moreover, students believe that they feel more responsible when they make autonomous decisions in which they become more personally engaged in deepening their understanding. Thus, teachers need to provide options for students on how the course of their learning takes place in order for them to feel motivated about their learning (Ebil, Salleh, \& Shahrill, 2020). According to Marshall (2008), a suitable environment cultivates delicate appraisal to students' achievement, adaptable because it provides what the learners need and is flexible. Self-reliance in learning also increases with the presence of accessible resources and time. Of equal importance, students must realize the curriculum imposed on them (Marshall, 2008) and be persuaded that contents are relevant for skill development and worthy for much more complex problems. 
The influence of self-regulation is compelling (Dignath \& Büttner, 2018) and has shown that self-regulation activates and influences different learners' cognitive, motivational, and emotional strategies in achieving their learning goals. After all, self-regulation is about becoming a self-reliant learner. Hoepfner and Koch (2015) stated that autonomous learning is driven by proactive selfdevising, self-monitoring, self-evaluation, and self-consciousness towards becoming an active independent learner.

Hoepfner and Koch (2015) suggest that collaborative work is necessary for the context of technical training. In an actual work situation, each member has his contribution towards the full completion of the project. Forman and Cazden (1994) explain that it requires the members to produce something essential in actual collaborative work. As such, if one of the members did not function, the project cannot be completed. Great emphasis on collaborative learning through teamwork is also stated in Hoepfner and Koch's (2015) guideline, emphasizing fostering good communication and leadership skills. This present study will further investigate how true collaborations between students can support the learners' self-reliance. Hence, it is essential to look at the elements of collaborative learning, such as teamwork, partnership, individual, and how they can contribute to autonomous learning effectiveness.

For students to feel responsible and confident in completing their tasks, Perry et al. (2002) suggested that peer collaboration could support the students' learning. When students are facing complex problems, it requires them to activate a high cognitive load, especially in the initial process of the task (Perry et al., 2002). Using peer collaboration, cognitive load is less, thus improving productivity. In addition, Whitebread et al. (2007) suggest that learners constantly find their effective study strategies by imitating models of their peers and testing out the study tactics. Furthermore, Perry and colleagues found that in collaboration, the peers could help individuals assess one another and report progress. These, in turn, create opportunities for other students to become a resource for learning. Khurshid (2020) found that "online collaboration in groups can enhance students' self-regulated learning skills and make them more independent learners in the virtual learning environment." (p. 188). In contrast to the findings by Polgampala et al. (2021), in which during the current pandemic, only $5 \%$ and $10 \%$ of students from Sri Lanka and New Zealand respectively perceived online learning as beneficial for autonomous learning if conducted on their own.

This present study investigates whether a different teaching strategy other than the traditional approach may affect the students' learning of Descriptive Statistics in Mathematics. The teaching strategy used is a self-reliant learning strategy where a student-centered teaching approach was utilized. Subsequently, the study also aims to explore whether group work collaboration affects the students' self-reliant learning strategy. The following research questions guide this study: How does self-reliant learning strategy affect students' performance in descriptive statistics? (RQ1) How does group work activity support the students' self-reliant learning strategy in learning Descriptive Statistics? (RQ2). 


\section{Methods}

This study followed the cycle of action research, plan strategically, act by implementing the intervention class designed, and observe outcomes to make evaluation and reflection and decide the next cycle of action research. A teaching method was designed and conducted systematically in the teaching and learning processes to investigate the outcomes as the result of the developed intervention class (Cohen, Manion, \& Morrison 2002). The outcomes were in the form of students' academic performance in the topic and the improvements in their learning strategies. It was also closely examined so that reflections for development can be made. The reflections were done within the duration of the intervention class itself and were made for future research.

The sample of this study involved two groups of first-year Diploma students in a Business course from one of the technical education institutions in Brunei Darussalam. The rationale for the two groups selected for this research is that two cycles of action research can be done where identified factors in the teaching method on the first group of students that needed to be improved will then be integrated into the second group. The main goal of this research was to determine the performance of students in Mathematics on the topic, descriptive statistics, using the intervention class design in the form of autonomous learning. The sample only focused on the students. Due to time constraints, 42 students were purposely chosen. The mean of their ages is 20 years old. The distribution of gender is shown in Table 1, and the majority are male students.

Table 1. Gender of students in the sample

\begin{tabular}{lcccccc}
\hline \multirow{2}{*}{ Groups } & \multicolumn{2}{c}{ Group 1 } & \multicolumn{2}{c}{ Group 2 } & \multicolumn{2}{c}{ Total } \\
Male & No. & \% & No. & \% & No. & \% \\
\cline { 2 - 7 } Female & 17 & 85 & 13 & 59.1 & 30 & 71.4 \\
\hline Total & 3 & 15 & 9 & 40.9 & 12 & 28.6 \\
\hline
\end{tabular}

This study used two cycles of action research, which started with Group 1 students, followed by Group 2 students. The intervention design for both groups was the same; the only difference was that the intervention integrated the improvements identified during the first cycle. The pre-test was administered to the sample in order to determine their prior knowledge of the topic. The first author, the teacher, used an online platform to give adequate reading materials relevant to descriptive statistics for the students to read before coming to the first class session. The classes used in this study consisted of three sessions, where the duration of each session lasted for 1.5 or 2 hours depending on their time slots in the timetable. During the first session, the first author initially taught and discussed the topic with the students for 45 minutes. Then the session proceeded to the assignment activity.

In the assignment activity, the students were given an open-ended group task in the form of a project assignment (see Appendix 1). A group of 4 or 5 members based on mutual topics they had in mind, a leader, was assigned by group vote. All groups had to work collaboratively for another 
45 minutes. Their collaborative works included determining the assignment goals, extensive planning, and decision-making before executing the task. Indirect and implicit guiding questions in the form of the 'learn and work' assignment design table were given to the students to give indirect guidance during the designing and planning stage (see Appendix 2).

The execution of the task was carried out during the interval between the first and second sessions ( 2 weeks). At this stage, the groups were expected to find appropriate sources, collect relevant data, perform consultations, and sort and analyze their data. It is also important to note that all groups must be aware and perform a self-reliant cycle, such as setting goals, planning, decision making, executing/monitoring, and evaluation to make improvements where necessary. This was reflected in the self-assessment forms given to each student at the start of the activity (refer to Appendix 3). Each student was required to fill in his or her self-assessment form during the assignment activity.

The presentations were carried out during the second of the class sessions. The presentation was divided into two main categories. The group leader of each team did the first presentation. They were required to answer questions that were given (See Appendix 4). The purpose was to allow the group leaders to present their performance as group leaders that can enhance the effectiveness of the group collaboration. This data was then used and contributed to analyzing the relation between group work collaboration and the students' self-reliance in their learning. The entire membership of each team carried out the second presentation. In this presentation, the groups must first present a report on the process of the 'learn and work' assignment activities (see Appendix 5), followed by the overall end product of their assignment. During the final class session (two days after the second class session) of this intervention design, a post-test was carried out, and the results were compared with the pre-test conducted at the initial stage of the intervention class design. The questions for the tests consisted of 13 questions extracted from the Mathematics for Business module past assessment papers and tutorial questions (see Appendix 6). Two experienced education officers who taught the same module in the sampled institution checked the suitability of the test items. They also agreed that the duration of the test could be conducted within one hour.

Video recordings of the classes were used to determine the crucial aspects of the intervention. The video outcomes were used to analyze students' interactions, emotions, actions, and reactions during the intervention classes. The observation checklist (see Appendix 7) was utilized to help identify significant facts and data about the students' learning strategies. The field notes data were then analyzed by finding patterns and also by using thematic coding.

In addressing RQ1, the comparison between the pre-and post-tests was used to measure the performance of the two groups of students quantitatively. This was done by utilizing descriptive statistics (i.e., mean, median, and standard deviation) and inferential statistics using Statistical Package for the Social Sciences version 23.0. The normality of the difference between the pre-and post-test scores was tested using the Kolmogorov-Smirnov test and found that the data distribution is not normally distributed. Hence non-parametric tests were used (i.e., Wilcoxon Signed-Rank test 
and Mann-Whitney U test). In addition, the students' end product of their assignment, which is reflected in their presentation, was also used to support the findings. Each group presentation was graded using the presentation rubric (see Appendix 8). Furthermore, data in the form of the first author's field notes were collected from the students' explanations during their presentation about their learning and work processes. The collected data were then analyzed by finding the emerging themes and then getting a better, in-depth understanding that can support the findings from the preand post-tests (Almalki, 2016).

The primary data used to answer RQ2 were obtained from the field notes of classroom observation, the video recording analysis, students' self-assessment forms that were submitted, and the outcomes of the presentation session. In order to make connections between the data collected from these multiple instruments, a triangulation method of analysis was used. Each instrument was analyzed to obtain learning processes that occurred during the intervention and its causes. These were then used to validate the emerging findings across these multiple instruments (Oliver-Hoyo \& Allen, 2006). Before conducting this research, permission was sought from the relevant authorities at the Ministry of Education and institution to seek their approval to conduct the study. The usage of tags and pseudonyms instead of the students' names was necessary to keep the anonymity of the students involved. Since all the participating students were all above 16 years old, their parents' consent was not required. The consent was only acquired from the individual student itself.

\section{Results and Discussion}

The preliminary analysis of the pre-and post-test scores was subjected to the test of normality. Shapiro Wilk of normality was applied, and it indicated a non-normal distribution of scores where the calculated $p$-value was less than .05. Therefore, a non-parametric test to further analyze the effect of the intervention was carried out, i.e., the Wilcoxon Signed-Rank test.

The students' pre-and post-test scores were subjected to the Wilcoxon Signed Rank test (Table 2 ). Descriptive statistics showed that measurement in the post-test (median $=33.00$ ) produced higher scores than in the pre-test (median $=3.00$ ). The Wilcoxon Signed-Rank test was converted into a $Z$ score of $-5.65, p=0.001$ (two-tailed). The test revealed a statistically significant increase in descriptive statistics topics following participation in the self-reliant learning strategies. The analysis is then extended to report the performance of the students according to gender. The findings indicate that the scores of male students were not significantly different from those of female students. Furthermore, the two groups did not differ in their test scores. 
Table 2. Summary of test scores, gender, and group analyses

\begin{tabular}{lcccccc}
\hline & & $\mathbf{N}$ & Mean (S.D.) & Median & $\mathbf{z}$ & Sig (2-tailed) \\
\hline Test & Pre-test & 30 & $5.43(6.029)$ & 3.00 & $-565^{\mathrm{a}}$ & .001 \\
\multirow{4}{*}{ Gender } & Post-test & 12 & $30.19(9.564)$ & 33.00 & & \\
& Male & 30 & $23.43(8.127)$ & 25.00 & $-1.81^{\mathrm{b}}$ & $>.05$ \\
\multirow{3}{*}{ Group } & Female & 12 & $28.08(3.919)$ & 25.50 & & \\
& Group 1 & 20 & $28.40(7.287)$ & 24.00 & $-1.49^{\mathrm{b}}$ & $>.05$ \\
& Group 2 & 22 & $26.00(7.528)$ & 25.50 & & \\
\hline
\end{tabular}

Descriptions: ${ }^{\mathrm{a}}$ Wilcoxon Signed Rank test; ${ }^{\mathrm{b}}$ Mann Whitney Test

The analysis for RQ1 also explored the students' performance according to the grade achieved from their presentations. The dependent variable had been set to be the difference between the pretest and post-test scores, with the independent variable to be the grade obtained by the students in their presentation. The grades are classified as shown in Table 3, where the highest mark for the outcome of the presentation is five, and the lowest is 0. When One-Factor Independent Measures ANOVA was conducted to compare any significant difference between the difference of marks between the pre-test and the post-test according to their grade, it proved to be not significant $\mathrm{F}(3,38)$ $=0.69, \mathrm{MSE}=56.65, \mathrm{P}>0.05$. This indicates that students' test scores did not vary significantly in their grade performance.

Table 3. Grade classification according to the range of presentation mark

\begin{tabular}{cc}
\hline Marks, $\boldsymbol{x}$ & Grade \\
\hline $5 \leq x<4$ & $\mathrm{~A}$ \\
$4 \leq x<3$ & $\mathrm{~B}$ \\
$3 \leq x<2$ & $\mathrm{C}$ \\
$2 \leq x<1$ & $\mathrm{D}$ \\
$1 \leq x \leq 0$ & $\mathrm{E}$ \\
\hline
\end{tabular}

In responding to RQ2, three sources of data were used in search of the emerging factors and themes that contributed in ways that students perceived how the group work supports students' selfreliant learning strategy during the intervention: (a) Individual performance in the activity was reflected in the self-assessment form where students are required to monitor and assess their progression in it; (b) Presentation of the assignment was another main output of the activity, and (c) Classroom observation made by the teacher during the sessions.

It was found that the group work activity helped each student to plan his or her learning strategies throughout the activity correctly. As evidenced from the 25 students who reported in their self-assessment forms, the other team members of their group shared learning strategies on how they intend to initiate their tasks. An example can be seen from Student A's self-assessment form shown in Figure 1. Meanwhile, from the classroom observations during the brainstorming among the group, the low-ability students learned best practice learning strategies from their teammates. 


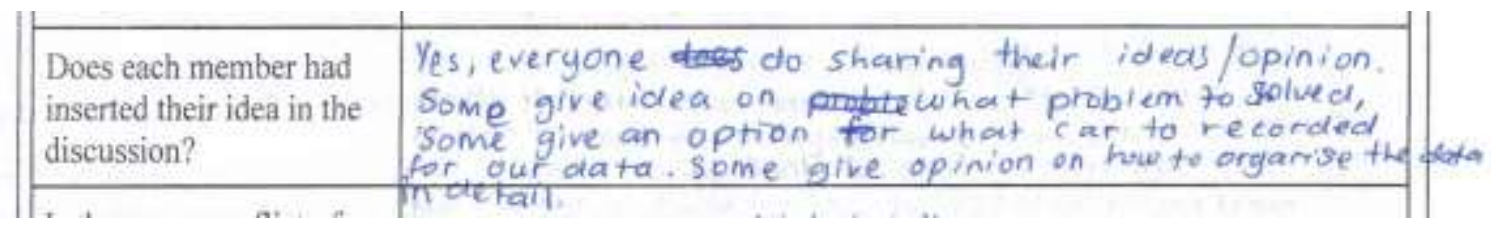

Figure 1. Student A's self-assessment form

It was observed that during the activity that the allocation of tasks among the group members motivated each member to finish their tasks. If at least one of the members cannot complete the assigned tasks given to them, the team cannot proceed towards completing the assignment. Thirtyfive students reported in their self-assessment forms that each member of their group was allocated tasks. Some samples can be seen from Students B, C, and D's self-assessment forms shown in Figures 2, 3, and 4, respectively. When some of the members were stuck in doing their tasks, the team members would help guide and give pointers to them. In addition, the distribution of tasks gave the students a more realistic view of how they would complete the assignment as they work together rather than them thinking that they were alone and without help. All group leaders reported in the presentation that the group members must work together to achieve the goal set. Moreover, all group leaders reported the importance of collaborating with other groups in sharing opportunities in improving the quality of their work.

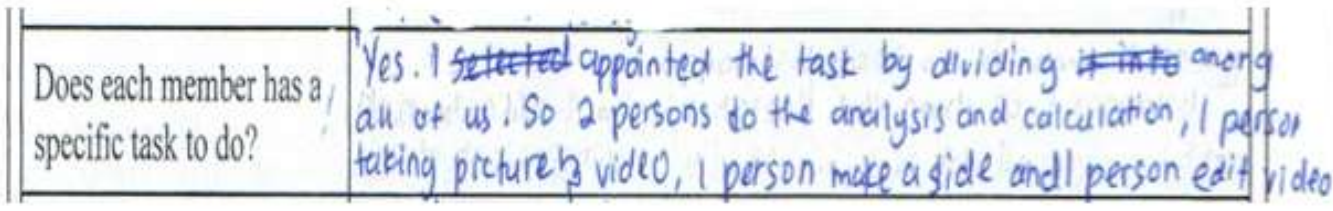

Figure 2. Student B's self-assessment form

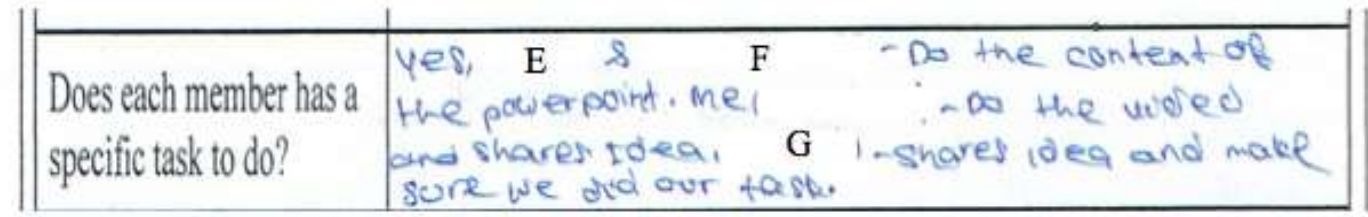

Figure 3. Student C's self-assessment form

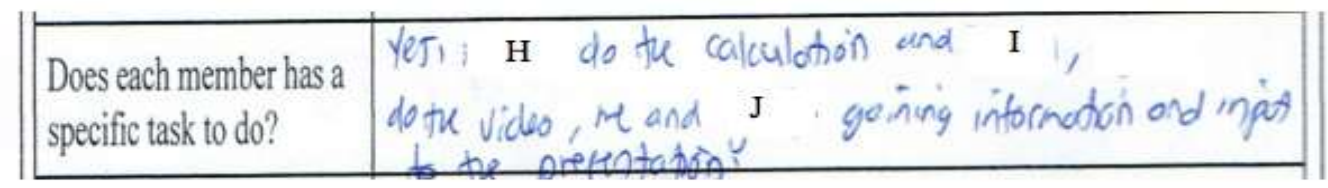

Figure 4. Student D's self-assessment form 
One of the purposes of electing the team leader was to remind the group members of the significance of monitoring and evaluating the quality of their work. The group activity created opportunities for the students to constantly check on the learning progression and help monitor the other team members. The 36 students who participated in the intervention reported in their selfassessment form that their team members confirmed their work, and feedback from any mistakes made had created room for more learning opportunities. This gives evidence that assessing other peers is an essential tool during learning. Learning is much more effective when instant and quality feedback was provided throughout the activity. Feedbacks were not limited to be given by the teacher only, but also by the team members. All groups reflected this on their presentation when they reported that their teammates' feedback during the activity helped them understand the topic much better.

Therefore, from the data collected from the self-assessment form, students report in the presentation and the classroom observation, pointing out that the group work activity helped the students' self-reliant learning strategy. This was through the three emerging themes, which were in terms of 1) the success in planning and designing their learning opportunities, 2) creating motivation in exploring the activities which have many learning opportunities, and 3) also helping the students to monitor and evaluate their learning progress.

In a study by Stoet and Geary (2012), there is evidence of a gender gap in math scores between male and female students. Such instances are not found in the findings of this present study. This supports a previous finding conducted by Gneezy et al. (2003) where there were no gender differences in mathematical scores. The study also noted that gender differences only occur in a competitive environment compared to a non-competitive environment (Gneezy et al., 2003). Hence this could explain the non-significant finding for gender differences in the test scores for this present study. In this research, the group activity has been set in a non-competitive learning environment. Therefore, the amount of determination and motivation for all students, regardless of gender, was expected to be similar. Moreover, male and female students were grouped, rather than having male versus female groups, in completing the activity.

Upon completion of the group activity, students were required to present their findings. The students' presentations were then graded using a rubric. An analysis was run to see if the difference in the pre-and post-test scores impacted the grade obtained by the students in their presentation. Findings revealed that there is no significant difference between the scores and presentation. However, we reasoned that this does not necessarily reflect that the self-reliant learning strategy was not successful. It is important to note that the rubric was designed to assess the outcome of the presentation only and did not include an assessment of students' autonomous learning. Factors such as confidence level may have also impacted students' presentation performance. Hence, the presentation did not reflect the self-reliant learning strategy of the students.

One of the factors of group work activity that helped the students' self-reliant learning was planning and designing their course of learning. The group activity required the students to have 
their tasks suggested in the 21st-century teaching and learning strategy (Laal, Laal, \& Kermanshahi, 2012). Since the distribution of tasks needs proper planning, this gives opportunities for each student to practice planning and designing for their learning. The students' success to successfully direct their learning and reach the desired goal started from planning the path to reach the latter (Puddicombe, 2006). Hence this research provided evidence that an element of planning in a selfreliant learning strategy could be nurtured by autonomous up activity. The students eventually gained the confidence to plan their learning independently. This research also showed that students tend to replicate study strategies. This is especially true of the lower ability students where they are willing to try a different strategy (Whitebread et al., 2007), and these created opportunities for the students to have effective learning strategies for them to adopt in the future.

In autonomous learning, students have the option to choose what learning resources to utilize. However, for learners who are still new to directing themselves, acquiring good resources is very challenging. When this research was conducted, team members were a good source of information. This proved beneficial for the low-ability students, as they were able to check their information with their peers before moving forward and boosting their confidence level at the same time. Discussions and brainstorming activities among the group members provided the foundation for each individual's understanding of the topic. When the foundation was laid, the students will be on their own, have the motivation to search deeper into the topic (Lee \& Hannafin, 2016). This was proven when the students in the intervention tended first to question themselves and then looked upon materials that they did not understand at home. This, in turn, led to the fact that group activity motivated the students to be self-reliant in their learning.

As autonomous learning includes students first have the ability to plan and design their learning. To ensure a self-reliant learning strategy is progressing, students must also have the ability to monitor and evaluate their learning during task execution (Hoepfner \& Koch, 2015). Through self-evaluation, students can reflect on their work, check their understanding, and identify any errors. Using group activity helps nurture self-reliant learning in a sense that aside from selfevaluation, students are also able to go to their team members to help evaluate their work and performance. This can be fruitful to the students as feedback from others can provide them different insights and promote growth (Laal et al., 2012; Perry et al., 2002). Therefore, from the findings of this present study, helping to assess and monitor each other's work is also essential in supporting their overall learning.

Furthermore, when students feel that they cannot progress further and feel that they cannot move forward, this can be demotivating for the students. Demotivation is also apparent when they feel alone in their learning (Pintrich, 2004). Thus, group work activity created opportunities for students to seek out answers, confirm their knowledge more comfortably with their peers where students would feel less afraid to do so and ask teachers or in front of the whole class as was found in this present research. 
What has set self-reliant learning strategy apart from other learning strategies is that it offers students to explore different options to check their knowledge and progression. The strategy does not restrict students to check or wait for teachers only but instead encourages students to seek out other channels, as evident in the findings of this research analysis, hence self-initiating their learning at the same time. Therefore, group activities provide students more options, such as resources, sources of information, another eye for evaluating, and all these create motivational factors for students to use self-reliant learning strategies.

\section{Conclusions}

This study provides the basis for applying self-reliant learning strategies in Mathematics lessons on descriptive statistics. Gender differences did not occur in this study as students recognized the non-competitive environment, and attention was directed to successful group collaborative learning, which is the main focus of the study. A self-reliant learning strategy is a new approach to the students. The group activity provided a valuable source of learning resources, which is more favorable for the low-ability students. Students were motivated through self-evaluation, and this process of obtaining feedback from team members helps nurture the autonomous learning of students. The intervention in this study was carefully designed to ensure every student would experience stages of critical reflection (e.g., setting goals, decision making, executing and monitoring, and evaluation) that offer students towards becoming self-reliant individuals. Among all the indicators in the reflection checklist, students mostly agreed that they perceived through the ability to plan the task, having team members as a source of information, and the gaining of ideas from different perspectives provided the most common skills that group activity can offer in the self-reliant learning strategies.

At the time of this research, a self-reliant learning strategy adapted from Hoepfner and Koch (2015) has never been tested practically. The findings of this present study may give helpful contributions in persuading teachers to consider other teaching method alternatives to the students. As found in this research, it proved that even by letting the students be more independent in their course of learning, there were positive changes in the students' performance. Hence this indicates that autonomous learning did lead to a positive impact on students, particularly students at the higher education level.

The fact that there is an increasing pace in this era on the need to gain as much knowledge quickly gives proof that the learning time in the class may not be enough to provide students with adequate learning opportunities. The importance for students to realize and be competent in directing their learning simultaneously is much needed. Therefore, nurturing lifelong learning is an excellent way to promote the latter. This can be done using a self-reliant learning strategy and embedding it into the students' professional skills.

It can be seen from this research that students were not used to being given independence in their learning. Hence, further research to explore how students can benefit when provided 
independence in their learning as early as possible in the education system and how it will affect the outcome of students' performance on their education are just some aspects to discover. Furthermore, this research was only conducted on the Mathematics topic of descriptive statistics. Future studies can be conducted on different Mathematics topics or even other subjects to help strengthen the findings of this investigation at a broader scope.

\section{References}

Almalki, S. (2016). Integrating quantitative and qualitative data in mixed methods research (challenges and benefits). Journal of Education and Learning, 5(3), 288-296. DOI: http://dx.doi.org/10.5539/jel.v5n3p288

Cambridge University Press. (n.d.). Self-reliant. In Cambridge Dictionary. Cambridge University Press. Retrieved from https://dictionary.cambridge.org/dictionary/english/self-reliant

Collins (n.d.). Learning. In Collins Dictionary. Collins. Retrieved from https://www.collinsdictionary.com/dictionary/english/learning

Cohen, L., Manion, L., \& Morrison, K. (2002). Research methods in education. London: Routledge Falmer.

Dignath, C., \& Büttner, G. (2018). Teachers' direct and indirect promotion of self-regulated learning in primary and secondary school mathematics classes-insights from video-based classroom observations and teacher interviews. Metacognition and Learning, 13(2), 127-157. DOI: https://doi.org/10.1007/s11409-018-9181-x

Ebil, S. H., Salleh, S. M., \& Shahrill, M. (2020). The use of E-portfolio for self-reflection to promote learning: A case of TVET students. Education and Information Technologies, 25(6), 5797-5814. DOI: https://doi.org/10.1007/s10639-020-10248-7

Forman, E. A., \& Cazden, C. B. (1994). Exploring Vygotskian perspectives in education: The cognitive value of peer interaction. In R. B. Ruddell, M. R. Ruddell, \& H. Singer (Eds.), Theoretical models and processes of reading (pp. 155-178). Newark, DE: International Reading Association.

Gneezy, U., Niederle, M., \& Rustichini, A. (2003). Performance in competitive environments: Gender differences. The Quarterly Journal of Economics, 118(3), 1049-1074. DOI: https://doi.org/10.1162/00335530360698496

Hoepfner, H. D., \& Koch, H. (2015). Self-reliant learning in technical education and vocational training (TEVT) [Practice and working paper]. Chiang Mai: RAVTE. Retrieved from http://tvet-online.asia/wp-content/uploads/2020/03/PWP_vol-4_Hoepfner_Koch.pdf

Khurshid, F. (2020). Online collaboration and self-regulated learning in online learning environment. Pakistan Journal of Distance and Online Learning, 6(1), 177-193.

Laal, M., Laal, M., \& Kermanshahi, Z. K. (2012). 21st-century learning; learning in collaboration. Procedia-Social and Behavioral Sciences, 47, 1696-1701. DOI: https://doi.org/10.1016/j.sbspro.2012.06.885

Lee, E., \& Hannafin, M. J. (2016). A design framework for enhancing engagement in studentcentered learning: Own it, learn it, and share it. Educational technology research and development, 64(4), 707-734. DOI: https://doi.org/10.1007/s11423-015-9422-5

Loyens, S. M., Magda, J., \& Rikers, R. M. (2008). Self-directed learning in problem-based learning and its relationships with self-regulated learning. Educational Psychology Review, 20(4), 411427. DOI: https://doi.org/10.1007/s10648-008-9082-7 
Marshall, G. (2008). Promoting independent learning by curriculum design and assessment in a taught postgraduate MRI programme. Radiography, 14(3), 238-245. DOI: https://doi.org/10.1016/j.radi.2006.11.001

Müller, N. M., \& Seufert, T. (2018). Effects of self-regulation prompts in hypermedia learning on learning performance and self-efficacy. Learning and Instruction, 58, 1-11. DOI: https://doi.org/10.1016/j.learninstruc.2018.04.011

Oliver-Hoyo, M., \& Allen, D. (2006). The use of triangulation methods in qualitative educational research. Journal of College Science Teaching, 35, 42-47.

Perry, N. E., VandeKamp, K. O., Mercer, L. K., \& Nordby, C. J. (2002). Investigating teacherstudent interactions that foster self-regulated learning. Educational Psychologist, 37(1), 5-15. DOI: https://doi.org/10.1207/S15326985EP3701_2

Pintrich, P. R. (2004). A conceptual framework for assessing motivation and self-regulated learning in college students. Educational Psychology Review, 16(4), 385-407. DOI: https://doi.org/10.1007/s10648-004-0006-X

Polgampala, S., Edirisinghe, M. N. S., Sudaraka, G. A. D., \& Patabedige, A. S. (2021). Perceptions of participants on online learning in the outbreak of COVID-19: Case study. Proceedings of the $7^{\text {th }}$ International Conference on Humanities and Social Sciences (IRCHSS-2021), University of Sri Jayewardenepura, Sri Lanka.

Puddicombe, M. S. (2006). The limitations of planning: The importance of learning. Journal of Construction Engineering and Management, 132(9), 949-955. DOI: https://doi.org/10.1061/(ASCE)0733-9364(2006)132:9(949)

Stoet, G., \& Geary, D. C. (2012). Can stereotype threat explain the gender gap in mathematics performance and achievement? Review of General Psychology, 16(1), 93-102. DOI: https://doi.org/10.1037/a0026617.

Whitebread, D., Bingham, S., Grau, V., Pasternak, D. P., \& Sangster, C. (2007). Development of metacognition and self-regulated learning in young children: Role of collaborative and peerassisted learning. Journal of Cognitive Education and Psychology, 6(3), 433-455. DOI: https://doi.org/10.1891/194589507787382043. 
Appendix 1. The assignment activity (Note: Adapted from Hoepfner and Koch (2015))

\section{Assignment Task}

The school authorities are currently in the process of allocating the budget to improve the infrastructure of the school. Only one improvement could be made within this annual budget. The authority intends first to identify the most significant problem that can be improved before deciding how to improve it. Suggestion for the most significant problem is welcome.

- The suggestion must include a detailed description of the problem, including quantitative statistical evidence that supports it.

- Further details on what can be improved for the problem are not required as this is only at the identification stage.

- The assignment has to be done in small groups of four participants, who independently plan, execute, control, and evaluate the tasks.

- Two weeks are allocated to complete the assignment.

- Upon completion, the suggestion must be presented orally.

Steps to do:

Setting goals and planning

- The assignment begins with students individually drafting ideas from relevant resources.

- The formation of the workgroup is primarily organized by the learner, with a maximum of 5 people per group.

- Then proceed with brainstorming and debates within the group to achieve consensus. Then the teacher approves the selection of a topic.

- The workgroup plans their procedure themselves.

Executing

- Documentation of the method is completed.

- The method was identified and carried out

- Improvements of the method if necessary.

Monitoring

- Objectives/Steps to success are identified.

- Steps to success are used to monitor progression.

- Consultation with the teacher.

Presentation and Evaluation

- Complete documentation of the findings.

- The group member agrees on the course of the presentation.

- The students present the process and findings in a plenary session consisting of the students and teacher.

- The presentation can include videos and pictures of various stages in doing the assignment.

Appendix 2. 'Learn and Work' assignment design table (Note: Adapted from Hoepfner and Koch (2015))

\begin{tabular}{|c|c|c|c|}
\hline $\begin{array}{l}\text { Activity for the } \\
\text { assignment }\end{array}$ & Learning objectives & $\begin{array}{c}\text { Information } \\
\text { sources }\end{array}$ & Guiding questions and hints \\
\hline $\begin{array}{l}\text { (1) Identifying the } \\
\text { problem }\end{array}$ & $\begin{array}{l}\text { Each group can identify an } \\
\text { appropriate challenge faced } \\
\text { by all students within the } \\
\text { schools. }\end{array}$ & $\begin{array}{l}\text { Internet (Social } \\
\text { media) }\end{array}$ & $\begin{array}{l}\text { - What factor can be changed to make school life } \\
\text { more comfortable and less frustrating to students? } \\
\text { - What data can be collected that can justify/evident } \\
\text { the identified problem? }\end{array}$ \\
\hline $\begin{array}{l}\text { (2) Selecting method } \\
\text { to gather data }\end{array}$ & $\begin{array}{l}\text { Each group can lay out the } \\
\text { method to collect the } \\
\text { appropriate data. }\end{array}$ & $\begin{array}{l}\text { Reference book, } \\
\text { internet, reading } \\
\text { material }\end{array}$ & $\begin{array}{l}\text {-What data can be collected that can justify/evident } \\
\text { the identified problem? } \\
\text { - What is the effective way to hear from the students } \\
\text { in the school, as many as possible? } \\
\text { - What is the effective way to collect accurate data? }\end{array}$ \\
\hline (3) Gather data & $\begin{array}{l}\text { Each group can carry out the } \\
\text { collection of accurate data. }\end{array}$ & $\begin{array}{l}\text { Reference book, } \\
\text { internet, reading } \\
\text { materials }\end{array}$ & $\begin{array}{l}\text { - Monitor your progression. } \\
\text { - Does everyone involved in this activity? }\end{array}$ \\
\hline (4) Analyse & $\begin{array}{l}\text { Each group can: } \\
\text { - Identify and carry out } \\
\text { analysis of data using the } \\
\text { appropriate measure in } \\
\text { descriptive statistics. }\end{array}$ & $\begin{array}{l}\text { Reference book, } \\
\text { internet, reading } \\
\text { materials }\end{array}$ & $\begin{array}{l}\text { - Which statistical tool can be used to summarise the } \\
\text { data? } \\
\text { - Which statistical tool can justify the accuracy of } \\
\text { your data? } \\
\text { - Is there any practical way to analyze the data? }\end{array}$ \\
\hline
\end{tabular}




\begin{tabular}{|l|l|l|l|}
\hline & $\begin{array}{l}\bullet \text { Use the descriptive } \\
\text { statistics to justify the } \\
\text { problem identified. }\end{array}$ & $\begin{array}{l}\text { What is the relation between analyzed data and the } \\
\text { problem identified? }\end{array}$ \\
\hline (5) Report & $\begin{array}{l}\text { Each group can present the } \\
\text { findings to other people. }\end{array}$ & $\begin{array}{l}\text { Reference book, } \\
\text { internet, reading } \\
\text { materials }\end{array}$ & Check the objective of your assignment. \\
\hline
\end{tabular}

Appendix 3. Self Assessment form to the students (Note: Adapted from Hoepfner and Koch (2015))

\begin{tabular}{|l|l|}
\hline Students Name & \\
\hline Student ID & \\
\hline Group Code & \\
\hline Assignment Group Name & \\
\hline
\end{tabular}

Please monitor the quality of your work during the work process. Comment and explain your progress for each criterion.

\begin{tabular}{|l|l|}
\hline Planning and Designing & Student Comments and Explanations \\
\hline Is the problem considered to be significant? & \\
\hline Are the resources gathered enough? & \\
\hline Has all information been considered? & \\
\hline Is the plan adequately detailed? & \\
\hline Are the plans logical and possible? & \\
\hline Has each member inserted his or her idea in the discussion? & \\
\hline Is there any conflict of ideas? & \\
\hline Has the conflict been resolved and agreement has been reached? (If any) & \\
\hline Did all members agree to the goal and plan set? & \\
\hline Does the plan involve all members to do the task? & \\
\hline
\end{tabular}

\begin{tabular}{|l|l|}
\hline Execution of tasks, monitoring, and evaluation & Student Comments and Explanations \\
\hline Did all members of the teamwork together? & \\
\hline Can the task be completed within the allocated time? & \\
\hline Did the plan work perfectly? & \\
\hline Did the tools use work ideally? (If any) & \\
\hline Were all data collected and analyzed correctly and accurately? & \\
\hline Is there something that can be improved? & \\
\hline What improvements have been made? (If any) & \\
\hline Did all members agree with the end product? & \\
\hline
\end{tabular}

\begin{tabular}{|l|l|}
\hline Allocation of tasks & Student Comments and Explanations \\
\hline Were the tasks allocated equally across the members? & \\
\hline Did each member have a specific task to do? & \\
\hline Did each member carried out his or her task on time? & \\
\hline Is there any conflict of opinion on the allocation of tasks? & \\
\hline Was the conflict resolved and agreement reached? (If any) & \\
\hline
\end{tabular}

Appendix 4. Question catalog for final assessment by the group leader (Note: Adapted from Hoepfner and Koch (2015)) 
Self-Reliant Learning Strategy in Vocational and Technical Education:

Insights from Group Collaboration

\section{Question Catalogue for Final Assessment (Group Leader)}

The group leader has to answer the following questions at the beginning of the overall presentation.

1. Have I placed too much or too little trust in the team members?

2. Have I done my best to encourage my team members to get personally involved in thinking and acting in the course of planning, executing, and evaluating?

3. Have I relieved the team members of too many responsibilities?

4. Have I failed to provide the necessary help?

5. Have my directives and instructions always been clear enough?

6. Have I been too overbearing with my knowledge and skills?

7. Have I monitored and evaluated too many things myself and stopped my team from doing it themselves? 
Appendix 5. Question catalog for final assessment for the entire group (Note: Adapted from Hoepfner and Koch (2015))

\section{Question Catalogue for Final Assessment (Entire Group)}

The success of the assignment activities

What have we learned? How did we learn it?

Designing opportunities, processing methods, and alternative solutions

- Why did we choose this particular problem instead of the other alternatives? What is/are significant implications can the problem be on the desired improvement?

- Which interests, needs, and objectives were taken into account or neglected, especially during the process of decisionmaking of the processes?

Collaboration

How effective was the collaboration within the teams, between the teams, and with the teacher?

Performance

- What did we do well during the performance of the assignment? What could we have done better?

- Which aspect of our work did we find satisfactory and which not?

- Is there anything we were not able to accomplish? Why?

- What particular problems emerged during the assignment? How were they solved?

- What have we learned from our mistakes? 


\section{Appendix 6. The pre-and post-test items}

\section{Test duration: 1 hour}

Student Name:

Group Programme:

Student ID:

\section{SECTION A: Answer ALL Questions. [15 Marks]}

1. Statistics is the study of data, which involves formulating the problem, collecting the data, organizing and analyzing the obtained data, and interpreting them to answer the stated problem. Two main types of data can be collected, which are discrete data and continuous data. Describe the definition of both of these data, include an example each: Discrete data [2]; Continuous data [2]

2. State three (3) ways of collecting statistical data. [3]

3. Explain the use of measures of central tendency in statistical analysis. [2]

4. Variance and standard deviation are two main measures of dispersion in statistics. They are used to compare the variation of the data set. If a data set has a higher value of variance and standard deviation, what does that mean? [2]

5. A quality assurance engineer is testing the performance of a batch of newly manufactured machines. If the performance is above 200 horsepower, then it will be released to the customer. The engineer tested 100 out of the total machines.

i. Using the data collected by the engineers, state what type of statistical analysis can be used to provide quantitative evidence of the problem and explain why. [3]

ii. The engineers also want to see the consistency of the machines' performance. State the type of statistical analysis that will be used for this purpose. [1]

SECTION B: Answer ALL Questions. [30 Marks]

(Give non-exact numerical answers correct to 2 decimal places)

1. The table below shows the speeds of 200 vehicles passing a particular point on Telisai-Lumut Highway:

\begin{tabular}{|c|c|}
\hline Speed (in $\mathbf{~ k m} / \mathbf{h})$ & Frequency \\
\hline $30>x \geq 60$ & 14 \\
\hline $60>x \geq 90$ & 30 \\
\hline $90>x \geq 120$ & 52 \\
\hline $120>x \geq 180$ & 71 \\
\hline $180>x \geq 210$ & 33 \\
\hline $210>x \geq 240$ & 0 \\
\hline
\end{tabular}

Find the following for the above set of data: i. Mean [4]; ii. Median [6]; iii. Standard deviation [4]

The Land Transport Authorities set the speed limit on the highway as $100 \mathrm{~km} / \mathrm{h}$. If there is any evidence that cars passing through the highway exceed the speed limit, the authorities will conduct more speed trap operations on the highway.

iv. Using your calculation/s above, explain if there is any statistical evidence to support this claim. [2]

2. A table glass manufacturer has developed less expensive technology for improving fire-resistant glass. Ten glass table sheets were selected for testing. Half of them were treated by the new technology while the other half was used for comparison. The fire tested both lots until they cracked. These are the results:

\begin{tabular}{|c|c|}
\hline \multicolumn{2}{|c|}{ Critical Temperature (glass cracked) $\left[{ }^{\circ} \mathrm{C}\right]$} \\
\hline Old Technology, $\boldsymbol{x}$ & New Technology, $\boldsymbol{y}$ \\
\hline 475 & 485 \\
\hline 436 & 390 \\
\hline 495 & 520 \\
\hline 483 & 460 \\
\hline 426 & 488 \\
\hline
\end{tabular}

i. Calculate the mean value of the old technology, $\bar{x}$, and the mean value of the new technology, $\bar{y}$. [4]

ii. Calculate the variance of the old technology, $\sigma_{x}^{2}$, and variance of the new technology, $\sigma_{y}^{2}$. [6]

iii. Using the mean and variance values, explain your recommendation on which technology is much better and more reliable. [4] 
Appendix 7. Group-work and learning strategy observation checklist (Note: Adapted from Hoepfner and Koch (2015))

\begin{tabular}{|l|l|}
\hline Setting Goals and Planning & Remarks \\
\hline Gathering relevant resources. & \\
\hline Discussion of ideas by the members. & \\
\hline Monitoring of the discussion session. & \\
\hline Identification of task goals. & \\
\hline Identifying the approaches to reach the goals. & \\
\hline Formulating possible courses of action. & \\
\hline Feasibility of the plan. & \\
\hline Timeline of the processes. & \\
\hline
\end{tabular}

\begin{tabular}{|l|l|}
\hline Decision Making & Remarks \\
\hline The decision for a concrete plan. & \\
\hline Consideration of all ideas for decision-making. & \\
\hline Consideration of alternatives. & \\
\hline
\end{tabular}

\begin{tabular}{|l|l|}
\hline Executing and Monitoring & Remarks \\
\hline Each member has a specific role in the task. & \\
\hline Communication between the members. & \\
\hline Effectiveness of task execution. & \\
\hline Monitor effectiveness of discussion. & \\
\hline Monitor effectiveness of processes. & \\
\hline Monitor the quality of the task. & \\
\hline Monitor the timeline of the processes. & \\
\hline
\end{tabular}

\begin{tabular}{|l|l|}
\hline Evaluation & Remarks \\
\hline Evaluation is constantly done throughout the overall task. & \\
\hline
\end{tabular}

Assessor's Name:

Group being Assessed:

Group Members' Name:

Date of Assessment:

Appendix 8. Presentation rubric

\begin{tabular}{|c|c|c|c|c|c|c|}
\hline \multicolumn{2}{|r|}{ Presentation } & \multicolumn{5}{|c|}{ Total Marks (Grade): } \\
\hline CRITERIA & 1: Unsatisfactory 2: Satisfactory 3: Good 4: Very Good 5: Excellent & 1 & 2 & 3 & 4 & 5 \\
\hline Content $(30 \%)$ & $\begin{array}{l}\text { Content is relevant and related to specified issues with no or minor } \\
\text { factual errors. Information presented in-depth and effectively supported } \\
\text { with data facts and statistics leading to correct conclusion, presented in an } \\
\text { excellent discussion. }\end{array}$ & & & & & \\
\hline Collaboration (15\%) & $\begin{array}{l}\text { Strong teamwork and engagement in presentation and questions and } \\
\text { answers sessions. }\end{array}$ & & & & & \\
\hline $\begin{array}{l}\text { Ability to convince } \\
(\mathbf{1 5 \%})\end{array}$ & $\begin{array}{l}\text { The pitch successfully convinces the assessor of how good the specified } \\
\text { problem is. Data presented are logical and supported by correct } \\
\text { calculation and interpretation. }\end{array}$ & & & & & \\
\hline Professionalism (15\%) & $\begin{array}{l}\text { The student completed the pitch with consistent professionalism } \\
\text { concerning: } \\
\text { - Pitching/presentation skills } \\
\text { - Attire }\end{array}$ & & & & & \\
\hline
\end{tabular}


Self-Reliant Learning Strategy in Vocational and Technical Education:

Insights from Group Collaboration

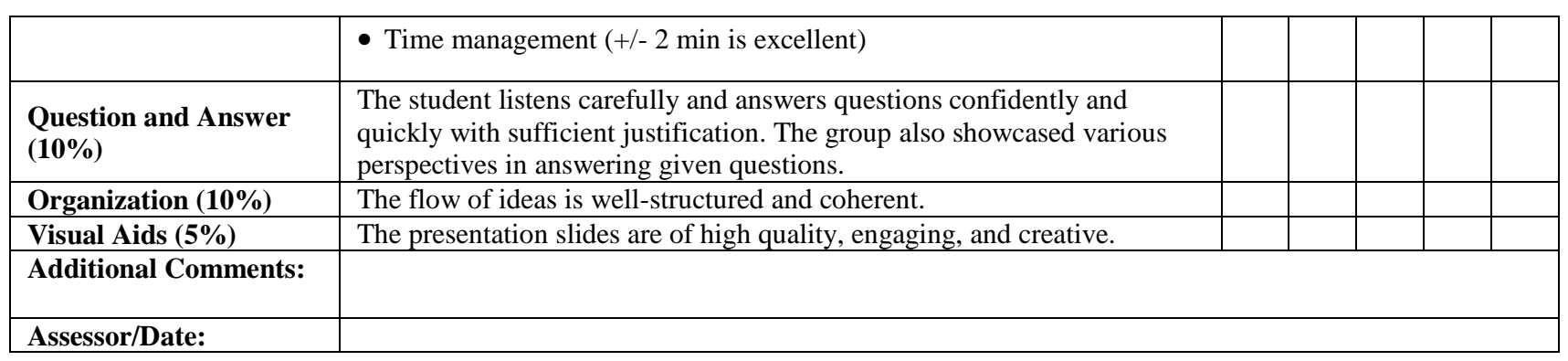

